\title{
Westonia első teljes magyar fordításának margójára
}

Since the end of the XIXth century Elisabeth Jane Weston has sunk into oblivion in Hungary. Recently the special Kossuth-issue of the journal "A Dunánál" dealt with the poetess, because she was probably one of the ancestors of the Kossuth family. Her writing had been analysed in the West before, her reception was held up by the fact, that her whole work (poems and letters) has not been published yet in Hungarian. Connected to the translation the author has analysed Weston's poetic technics, and claims, that the poetess wanted to slip on the mask of an ancient literary heroin or that of a poetess in exile. ${ }^{1}$

„Westonia neolatin költészete méltán figyelmet érdemel. Nem csak mint Kossuth ösanyja érdekes számunkra, hanem mint hiteles tanúja annak a prágai manierizmusnak, amelyről Magyarországon oly keveset tudunk" fogalmaz a költőnőről Szörényi László A Dunánál Kossuth-számában megjelent tanulmányában. ${ }^{2}$ A Kossuth-családdal feltételezhető kapcsolat Szőcs Gézát indította további kutatások ösztönzésére, hogy a költőnőt kiemelje a feledés homályából. ${ }^{3}$ A Westonra irányuló figyelem a halála után

1 A publikáció elkészítését az MTA-SZTE Antikvitás és reneszánsz: források és recepció Kutatócsoport (TK2016-126) támogatta.

2 SZÖRÉNYI László, Kossuth Lajos neolatin költőnő ösanyja, Elisabetha Iohanna Westonia, A Dunánál, 2(2003), 3. sz., 12-15.

3 Szőcs ösztönözte $A$ Dunánál című kulturális lap Kossuth-számában a család feltételezett ősanyja alakjának minél sokoldalúbb megvilágítását. Gudenus János József lapszámban idézett kutatásai tisztázzák, hogy Kossuth Lajos Weber-felmenői anyai ágon valóban Weber János valamelyik gyermekének leszármazottai - hogy melyikhez, mondja Gudenus, további 
száz évvel megjelent utolsó gyưjteményes kiadása után az utóbbi évtizedekig meglehetősen alábbhagyott. ${ }^{4}$ Neve fel-feltünik ugyan nagy kompendiumokban, ${ }^{5}$ de itthon csak a XIX. század végén, tőlünk nyugatra pedig csak a XX. század utolsó évtizedeiben, a női költészet kutatásának fellendülésével kezdik újra kutatni. Cseh nyelvü kutatása ugyan létezett a múlt század húszas éveiben is, ${ }^{6}$ de ennek eredményeit csak az utóbbi években dolgozták bele szélesebb körben olvasott nyelveken megjelenő kutatási eredményekbe. Itthon Szőcs Géza kezdeményezte Westonia hagyatékának teljes magyar fordítását is a 2003-as torontói teljes kiadás ${ }^{7}$ alapján, eladdig

kutatások tisztázhatják: GUDENUS János József, Adalékok a Kossuth család történetéhez, A Dunánál, 2(2003), 3. sz., 23.

4 Elisabetha Ioanna WeSTONIA, Opuscula, quae quidem haberi potuerunt, ed. Joannes Christophorus KALCKHOFF, Francofurti, Cramer, 1724.

${ }^{5}$ L. Latkóczy adatait a rendelkezésére álló életrajzi források felsorolásában (LATKÓcZY Mihály, A humanismus egy elfeledett nöalakja: Elisabetha Joanna Westonia, Eperjes, 1891. Különnyomat az eperjesi kir. kath. főgymnasium Értesitőjéből, 1. j., 50), ezek azonban, legalábbis a XVIII. századiak leginkább egymásból merítenek, és jó, ha a Weston saját verseiből kivehető adatokat feldolgozzák. Utóbbiak közül az első Pelzel költő- és művészlexikona (Franz Martin PeLzel, Abbildungen böhmischer und mährischer Gelehrter und Künstler nebst kurzen Nachrichten von ihren Leben und Wirken, III, Prag, 1777, 71-77), és nagyra tartja Brotherton esszéjét (Mary BROTHERTON, A Forgotten English Poetess, Macmillen's Magazine, 1870, 22, 93-99), mely utolsó két lapján latin-angol párhuzamos szöveget közöl Weston néhány verséről. L. LATKÓCZY, i. m., 49-50, 1. j. Latkóczyhoz nem jutott el Mary Hays monstre életrajz-gyüjteménye, melyet a feminizmus egyik előfutáraként emlegetett sokoldalú szerző (1759-1843) 1803-ban publikált hat vaskos kötetben, és amely három év múlva Chicagóban is megjelent (Female biography; or, Memoirs of illustrious and celebrated women, of all ages and countries, ed. Mary HAYS, London, 1803). Ez az életrajz azonban nem mint tudományos forrás jelentős, hanem mint egy, a világ összes híres és jelentős nőjét, asszonyát felvonultató hatalmas gyüjtemény része: versei közül érdekes témájuk miatt csak néhányat idéz, például a könyvnyomtatás feltalálásáról szólót, és - mint Hays fogalmaz - több Aisópos-mesét is latinra fordított (462-463).

${ }^{6}$ Karel Hrdina, Dvě prácě z dějin českého humanismu, Listky filologické, (55)1928, 14-19; Bohumil RYBA, Westoniana, Listky filologické, (56)1929, 14-28.

7 Elizabeth Jane WeSTON, Collected Writings, ed., transl. Donald CheEneY, Brenda M. HOSINGTON, D. K. MONEY, Toronto, Buffalo, London, 2000. 
csak a Latkóczy kismonográfiájában lefordított verseket ismerhette a latinul nem olvasó magyar közönség. ${ }^{8}$

Elizabeth Jane Weston, latin költői nevén Elisabetha Ioanna Westonia élete legelső hónapjai után Prágában élte le rövid életét, sírja a prágai Szent Tamás templomban jelenleg is látható. Versei címzettjei olyan uralkodók, mint II. Rudolf vagy I. Jakab, illetve Rudolf prágai udvarának kiemelkedő személyiségei, a korabeli európai kulturális közélet nagyságai, köztük annak legkiemelkedőbb alakjai. ${ }^{9}$ Mostohaapja a császári alkimista, Edward Kelley Dr. John Dee munkatársa (Kelley szerepéről az álláspontok megoszlanak erről később). ${ }^{10}$ Ebből a körülményből érthető, hogy a költőnő iránt élénken érdeklődött a csehországi kutatás. Ha áttételesen is, de Westoniának köze van Eperjeshez is - ez itthon a XIX. század végén a tudós gimnáziumi tanárt, Latkóczy Mihályt vezette Westonia életrajzának, költészetének és levelezésének feltárására. ${ }^{11}$ Latkóczyt 1886-ban helyezték Eperjesre az ottani katolikus fögimnáziumba, és öntudatos hazafiként - egyebek mellett az eperjesi Széchenyi-kör titkára volt - a maga részéről Eperjes és Sáros vármegye humanista múltjának kutatásával óhajtott hozzájárulni városa történetének feltárásához. Így ír erről: "Ilyen [ti. humanista, és tárgyválasztásukban praktikus] írók voltak hazánkban és szükebb értelemben véve Sárosvármegyében: Bocatius, II. Rudolf magyar király és osztrák császár koszorúsa, Werner György, Sárosvár híres parancsnoka, ilyen kivált Weber János, Eperjes fóbírája, Felsőmagyarország gyógyszerésze és a murányi Vénus udvari orvosa."12

\footnotetext{
${ }^{8}$ Latkóczy több Weston-verset fordít illusztáció gyanánt: a Horatius átlal használt strófákat rímes magyar versekben, a hexametereket és a párverseket pedig az eredeti formában tolmácsolja.

${ }^{9}$ LATKÓCZY, i. m., 22-23.

10 Susan BASSNETT, Absent Presences: Edward Kelley's Family in the Writings of John Dee = John Dee: Interdisciplinary Studies in English Renaissance Thought, ed. Stephen CLUCAS, Springer, 2006, 291.

11 Szenczi Molnár Albert személyesen is találkozott Westoniával Prágában 1604-ben, amikor barátai, Johann Konrad Rummel és a jogtudós Konrad Rittershausen levelét adta át neki: P. VÁSÁRHELYI Judit, The role of Albert Szenczi Molnár in the Exchange of Ideas and Political Knowledge among the European Calvinist Principalities in the Early Seventeenth Century = A Divided Hungary in Europe: Exchanges, Networks and Representation, 1541-1699, I, eds. Gábor AlmÁsI, Szymon BRZEZIŃSKI, Ildikó HORN, Kees TESZELSZKY Áron ZARNÓcZKI, Cambridge, Cambrige Scholars Publishing, 2014, 140.

12 LATKÓCZY, i. m., 3.
} 
Latkóczynak célja volt, hogy teljeskörüen tárja fel az esetleg még lappangó kéziratos hagyatékot, a Westonia életével kapcsolatos testimoniumokat és a róla szóló irodalmat. Nagy erőfeszítéseket tesz: levelez, konzultál, kollacionáltat, filológiailag kifogástalan munkát végez. ${ }^{13}$ Éppen ezért Szörényi Lászlóval együtt csak fájlalhatjuk, hogy munkájának eredményét nem ismerhette meg a nemzetközi publikum. ${ }^{14}$ Mivel a Westonia-képet az 1920-as évek végi cseh szakirodalom bevonásával Bassnett, ${ }^{15}$ a Hosington-Cheney-kiadás, majd Schibel a kétezres évek elején sok helyen kiigazította, ${ }^{16}$ szenteljünk először is figyelmet az életrajznak és pályaképnek a Latkóczy által rögzített consensus philologorum alapján, majd tekintsük át, hogy hol változtatott mindezen az új Westonia-életrajz. Mint látni fogjuk, a Prágában tengődő angol főrendi lány képe nagyot változott és jelenlegi tudásunk szerint, az előzőtől teljesen eltérő jelleget öltött.

Latkóczy Westoniát a régi arisztokrata Weston-család egyik, katolikus ágából eredezteti. A születése körüli időszakban a katolikusokat Angliában keményen üldözik. Westonia apja, John Weston ekkoriban Londonban tartózkodik - itt születik kislánya 1582. november 2-án. Westonia második gyermek: bátyja John Francis valamivel idősebb. Az apa a 80-as évek vége felé kénytelen elhagyni Angliát minden bizonnyal a fia taníttatása miatt: az akkori angol törvények szerint külföldön tanulni hazaárulás, Weston pedig vallási okokból nem akarta Oxfordban vagy Cambridge-ben taníttatni a fiát. ${ }^{17}$

A pápista család rövid franciaországi és itáliai tartózkodás után végül Csehországban, Rudolf prágai udvarában talál menedéket. Ez az udvar akkoriban nagyon sokak: tudósok és kalandorok számára is vonzó, John

\footnotetext{
${ }^{13}$ LATKÓCZY, i. m., 49-50, 1.j.

14 SZÖRÉNYI, i. m., 13.

15 Susan BASSNETT, Elizabeth Jane Weston - the Hidden Roots of Poetry = Prag um 1600, ed. Eliška FUČIKOVÁ, Freren, Emsland, 1988, 9-15; UÖ, Revising a Biography: A New Interpretation of the Life of Elizabeth Jane Weston (Westonia), Based on her Autobiographical Poem on the Death of her Mother, Cahiers Elisabethains, (37)1990, 1-8; BASSNETT, Absent Presences..., i. m., 285-294.

16 Wolfgang SCHIBEL, Westonia poetria laureata: Rolle, Schicksal, Text = Lateinische Lyrik der frühen Neuzeit. Poetische Kleinformen und ihre Funktionen zwischen Renaissance und Aufklärung. 1. Arbeitsgespräch der Deutschen Neulateinischen Gesellschaft in Verbindung mit der Werner-ReimersStiftung Bad Homburg, hrsg. Beate CZAPLA, Ralf Georg CZAPLA, Robert SEIDEL, Tübingen, 2003, 278-297.
}

17 LATKÓCZY, i. m., 6-7. 
Weston nyugalmat talált a katolikus uralkodó birodalmában. Pártfogója a befolyásos Wok Rosenberg gróf lett, Brüx városában telepedett le nem messze Prágától. Itt folyt a két gyermek nevelése: angol anyanyelvükön kívül németül és csehül is jól megtanultak. Latkóczy feltételezése szerint a kis Elizabeth e nyelveken kívül a család rövid franciaországi és itáliai tartózkodása alatt tanult meg franciául és olaszul. ${ }^{18}$ A gyermekek otthoni nevelője John Hammond volt, akinek nevelése a későbbi költőnőt igazi docta puellává tette, míg bátyja egy idő után a katolikus ingolstadti egyetemen tanulhatott tovább két évig, ahol meglehetősen egyedül érezhette magát, mert rajta kívül csak egy angol van bejegyezve a matrikulába - de szerető húga levelei ebben az időszakban szerencsére vigaszt jelentenek neki. ${ }^{19}$

John Weston kis birtokot vehetett Brüxben, és kölcsönökből virágoztatta fel, azonban 1597-ben hirtelen meghalt, és a hitelezők hirtelen elkezdték kintlévőségüket követelni. A birtokot a család eladta, kifizette a hitelezőket, és még elegendő tőke maradt volna a megélhetésre is, csakhogy a birtok ára és hitelezők követelésének különbségét az özvegy valamilyen oknál fogva nem kaphatta meg. Anya és lánya Prágába költözik, ahol befolyásos udvari embereken keresztül próbálják elérni, hogy Rudolf a konfiskált pénzt adja vissza. Westonia megírja Rudolfnak címzett versét, ${ }^{20}$ melyben emlékezteti a nagylelkűség királyi erényére. Számos költeményt intéz olyan személyeknek is, akik segíthetnek a perújrafelvételben és a család kártalanításában - erre valós esélyük azonban, mint Westonia 1598. október 2-án kelt, bátyjának Ingolstadtba írt levele bizonyítja, alig van. Westonia és anyja saját jövedelem híján pártfogóik jóindulatára volt bízva - erről szintén

18 Tegyük hozzá, hogy az, hogy a fiatal hölgy képében ekkora szerepet játszik poliglottsága, kapcsolatba hozható azzal a ténnyel, hogy Westonia csodagyereknek indult. Tény, hogy méltatói nyilatkozatain kívül többnyelvüségéről semmiféle bizonyítékunk nincs, kizárólag latin nyelvű versei és levelezése maradt fenn. Ezt természetesen úgy is felfogható, hogy Westonia irodalmi tevékenységét magától értetődő módon a kor irodalmi köznyelvén, latinul folytatta.

${ }^{19}$ LATKÓCZY, i. m., 5-10.

20 A hivatkozott verseket az egyszerüség kedvéért a fent idézett Chesey-Hosingot-féle kétnyelü kiadás lapszámaival idézem $\mathrm{Ch}-\mathrm{H}$ rövidítéssel, a lapszám megadásával. A szóban forgó vers: $\mathrm{Ch}-\mathrm{H}, 2-5$. 
tanúskodnak Westonia hol támogatást kérő, hol érte hálát mondó alkalmi költeményei. ${ }^{21}$

Ebben a reménytelen helyzetben „alkalmazott irodalom”-nak indul Westonia költészete - ez érthető, a fiatal lánynak kellett valamit tennie a család helyzetének javításáért. Ugyanakkor életrajzírói Latkóczytól Bassnetig és Schibelig adósok maradnak annak a kérdésnek a megválaszolásával, amit már Latkóczy is fölvet: kinek az ötlete lehetett, hogy Westonia költői pályára lépjen, és egyúttal az is elterjedjen róla, hogy csodagyerek. ${ }^{22}$ Schibel mindenesetre felhívja a figyelmet, hogy Westonia legkorábbi nyomtatványainak címei csúsztatásoktól sem rettentek vissza, hogy a hajadon költőnőt (virgo docta) ilyen színben tüntessék fel. ${ }^{23}$ Hogy a cél mindezzel mi lehetett, egyértelmű: minél több rajongót szerezni Westoniának - a költői siker befolyásos barátokat, támogatókat hozhatott, akik aztán a családon anyagilag is segíthettek, vagy legalábbis előmozdíthatták a perújrafelvétel ügyét. Egy sor, valóban befolyásos ember tünik fel Westonia verseinek címzettjei között. Egyikük, Barvitius, Rudolf személyi titkára, egy másik Philip de Monte, a császár zenekarának vezetője, köztük van Pontanus, brüxi születésű prágai kanonok és Nicolaus Maius törvényszéki tanácsos. ${ }^{24}$ Latkóczy a már említett Rosenberg ottani befolyásának tudja be azt a tényt is, hogy Westonia első kiadványa, a császárhoz szóló költeménye végül nem Prágában, hanem Bernburgban jelenik meg - magát az ötletet pedig, hogy Westonia mint költő próbáljon Rudolf látóterébe kerülni, Barvitiusnak tulajdonítja. ${ }^{25}$

Közben újabb megpróbáltatás éri a családot: hirtelen meghalt Westonia bátyja - a fiatal költőnő egyik legszebb versében siratja el azzal a „szent háromsággal" együtt, amelyet ők ketten anyjukkal együtt alkottak, - és nyilván tőle várták, hogy a család egyetlen élő férfitagjaként átvegye apja szerepét. Henrik de Pisnitz csehországi alkancellár veszi pártfogásába a hajadont és anyját, de Zdeněk Lobkovic főkancellár közbenjárása ellenére is csak

\footnotetext{
${ }^{21}$ LATKÓCZY, i. m., 8-10.

22 LATKÓCZY, i. m., 13; BASSNETT, Absent Presences..., i. m., 290; SCHIBEL, i. m., 279.

23 SCHIBEL, i. m., 280.

24 SCHIBEL, i. m., 280-281.

${ }^{25}$ LATKÓCZY, i. m., 14.
} 
nagysokára sikerült a császár elé vinni Westonék ügyét, és elérni az ügy felülvizsgálását.

Míg erre várnak, Westonia életében két kedvező változás következik be: az egyik házassága Johannes Leóval, a másik pedig a költői siker. Az utóbbihoz hozzájárult a korabeli res publica litteraria nagyjainak elismerése szerte a korabeli Európában. Közéjük tartozott az angol John Dousa, a németalföldi Daniel Hensius, Franciaországban pedig Scaligerék - igazi költővé válásához azonban ténylegesen leginkább a mellrichstadti Paulus Melissus Francus, azaz Paul Schede járult hozzá. Maga Melissus 1561-ban lett koszorús költő, ettől kezdve tudatosan figyeli a feltörekvő tehetségeket a heidelbergi könyvtárban. 1601-ben babérkoszorút küld Westoniának egy elismerő költeménnyel kíséretében, majd az elsőt további kettővel toldja meg. ${ }^{26}$ Westonia kora egyetlen költőnője lett, aki a res publica litteraria egy már elismert polgárától apja meg ezt a kitüntetést. Ugyanekkor tesz szert Westonia élete másik kiemelkedő jelentőségü támogatójára, Martin von Baldhofenre. Von Baldhoven újabb kapcsolatokhoz segítette, és sajtó alá rendezi, valamint segít megjelentetni Westonia első gyüjteményes kötetét. Az időszak végére fenmaradt levelezések tanúsága szerint Westonia beszédtéma a legmagasabb irodalmi körökben. ${ }^{27}$

A másik kedvező fordulat Westonia életében ezzel egyidőben, hogy Johannes Leo, udvari jogász kéri meg a kezét. Leóval való kapcsolata maga sem független a költői tevékenységtől. A költészet hozza össze vele: az első kiadás munkálatai közepette Weston tőle kér véleményt verseiről. Latkóczy szerint Leo tanácsára jelenteti meg Weston gyüjteményes kötetét az Odera menti Frankfurtban. ${ }^{28}$

Westonia anyagi értelemben révbe ér Leo feleségeként. Hogy boldog volt-e vele vagy nem, nem tudni - levelezése sem ezt, sem az ellenkezőjét nem állítja. Az örökséget ekkorra még nem kapta vissza. 1604-ben von Baldhofen javaslatára dicsőítő költeményt írt I. Jakabnak, míg az akkoriban

\footnotetext{
${ }^{26}$ John FLOOD, Poets Laureate in the Holy Roman Empire: A Bio-bibliographical Handbook, 1, A-C, Berlin, New York, 2006, Introduction ccx.

${ }^{27}$ LATKÓCZY, i. m., 23-25.

${ }^{28}$ Poëmata Elisab. Joan. VueSTONIAE, Anglae, Studio ac opera G. Martinii a BALDHOFEN, Silesii collecta $\mathcal{E}$ amicis communicata, Francofurti ad Oderam, Typis Sciurinis, 1602; LATKÓcZY, i. m., 32-33.
} 
Leidenben élő von Balhoven személyesen járt közben a királynál, amikor az Angliába hívta - ugyanis katedrát akart adni neki. Különféle intrikák miatt Jakab közbenjárása Rudolfnál éveik késik - közben Westonia Prágában él férjével. Végül Jakab eléri Rudolfnál, hogy a vagyon visszaszolgáltatása megtörténjen. Westonia közben tovább halad előre a sikeres költői pályán: már második gyüjteményes kiadását készíti elő Parthenicôn címmel a címlapon feltüntetett adatok szerint újfent von Baldhoven szerkesztői segítségét igénybe véve. ${ }^{29} \mathrm{~A}$ kiadások kérdéséről azonban bővebben később.

Westonia életrajzának bizonyos részeit Karel Hrdina és Bohumil Ryba teljesen újraírta 1928-29-ben, de eredményeik csak Bassnett dolgozataiban és J. W. Binns ismertetésében kerültek be az irodalomtörténeti köztudatba. ${ }^{30} \mathrm{~A}$ korabeli plébániai anyakönyv szerint John Wessone és Joane Cowper 1579. június 29-én kelt egybe az oxfordshire-i Chipping Nortonban - az arát, aki Thomas Cowper lányaként van bejegyezve, ugyanott keresztelték meg 1563. június 28-án. Joane és John első gyermekét Johnt 1580. július 23-án, Elisabethet (apja neve ebben a bejegyzésben már John Weston) valamikor 1581. március és októbere között tartották keresztvíz alá. ${ }^{31}$ John Weston temetési bejegyzésénél, 1582. május 6-án foglalkozásként „clark” áll, az újabb Weston-életrajzok ezért vonják kétségbe a költőnő arisztokrata Westonoktól való származását. Joane és két gyermeke már nem férje oldalán kerül Európába, ezzel az az adat is ködbe vész, hogy a katolikus család az Erzsébetkori Anglia pápistaellenessége miatt hagyja el a királyságot. Joane Cowpert John Dee munkatársa, Edward Kelley vette el, akit Mihály arkangyal egy héttel John Weston temetése előtt int, hogy nősüljön meg. Az angyali üzenet két nappal Weston temetése előtt megismétlődik. Kelley feleségül veszi a friss özvegyet, s az már férje, valamint John Dee és neje oldalán utazik a rá közvetkező évben Európába. John Dee naplójában Kelley mostohagyermekei nem szerepelnek, ami egybevág azzal a Westonia anyja halálára írt verséből

\footnotetext{
29 Parthenicôn Elisabethae Ioannae Westoniae... Opera ac studio G. Mart. à BaLdHOVEN, Sil. collectus... Nunc denuo amicis desiderantibus communicatus, Pragae, Sessius.

${ }^{30}$ Karel Hrdina és Bohumil Ryba teljesen újraírta 1928-29-ben, de eredményeik csak Bassnett dolgozataiban (1988; 1990): HRDINA, 6. jegyzetben i. m., 14-19; RYBA, 6. jegyzetben i. m., 14 28. - vö. SCHIBEL, 279, 3. j.

31 Brenda M. Hosington, Elizabeth Jane Weston (1581-1612) = Women Writing Latin: Early Modern Women Writing Latin, 3. ed. Laurie J. CHURCHILL, Phyllis R. BROWN, Jane E. JefFreY, New York, London, 2002, 217-218.
} 
kikövetkeztethető adattal, hogy a gyermekeket átmenetileg az anyai, illetve apai nagyanyáknál hagyták. Az úticél Lengyelország, majd Prága, II. Rudolf udvara volt, ahol Dee csak 1589-ig marad, majd visszatér Angliába. Munkatársa, Kelley Csehországban telepszik le, talán azért, mert fivére, Thomas felesége Heinrich von Pisnitz Ludmilla nevü lánya volt, és fivére apósa támogathatta az udvarnál. Rövidesen Rudolf udvari alkimistája lesz, a császár eques aureusszá üti - ekkortól az ír nemesi származásra utaló de Imany nemesi toldalékot használja neve mellett, holott Dee-vel való megismerkedése idején még Talbot a neve. A Westonia halála utáni századok során kialakult regényes és romantikus életrajz tehát az első Weston-kiadás címében megjelenő nobilis tituluson és a költőnő saját magára vonatkozó utalásain kívül éppen ezen alapul, vagyis azon, hogy Kelley fénykorában nemesi származásúnak akarja feltüntetni magát. Kelley szerető apaként neveli mindkét mostohagyermekét: Johnt Ingolstadtban taníttatta 1598-tól, s ebben Heinrich von Pisnitz is támogatta, míg a fiú tragikusan korán el nem hunyt 1600-ban. ${ }^{32}$ Westonia képzettsége, különösen latintudása és irodalmi múveltsége az újabb életrajzok szerint is John Hammondnak köszönhető, akit Bassnett feltételezése szerint Westonia John Dee gyermekeivel együtt hallgathatott. John Dee feljegyzései említik, hogy egy évre tanárnak szerződtette gyermekei mellé Hammondot, és Westonia később egy a Poëmatában publikált verset is címez neki, tehát kapcsolatuk nem kevés ideig tarthatott. ${ }^{33}$ Maga John Dee a gyermekei mellé fogadott mester később nem emlegeti, bár ebből nem következik feltétlenül, hogy a továbbiakban már nem alkalmazta. Westonia a jelek szerint meglehetős nyelvtehetséggel volt megáldva: kiválóan megtanult latinul és jó néhány élő nyelven is. Ami Westonia irodalmi müveltségét illeti, ennek lehetséges területeit Latkóczy Szinyei Merse György, a prágai magyar kancellária pecsétőre könyvtára alapján igyekszik rekonstruálni. ${ }^{34}$ Ebben a bibliotékában megvolt Horatius Ars poeticája, Cicero levelezése, Sallustius és Valerius Maximus munkái és néhány humanista, köztük Leonardus Arestinus és Christophorus Landinus

\footnotetext{
32 BASSNETT, Absent Presences..., i. m., 291.

33 BASSNETT, Absent Presences..., i. m., 292 szerint a Westonia által Johannes Hammoniusként emlegetett férfi alighanem ugyanaz a John Hammond, aki 1579-ben a cambridge-i Trinity College tagja volt, és 1605-ben végzett orvosként, majd I Jakab és Henry herceg orvosa volt.

34 LATKÓCZY, i. m., 9.
} 
művei is, de ott voltak a korban divatos asztrológiai és alkímiai kézikönyvek is - és Westonia versei utalásai alapján maga is jártasságot szerzett e tudományokban, vagy legalábbis nagyra tartotta őket.

Az életrajz hitelezőkkel és az apa halálával kapcsolatos részét úgy igazították ki, hogy a vagyon és az adósság valójában Kelley-é volt, akit 1591ben gyilkosság miatt börtönöztek be először, majd később még többször börtönbe került, ahol öngyilkos lett vagy szökés közben halt meg 1597 körül. ${ }^{35}$ A hitelezők Kelley adósságai miatt kezdték szorongatni a családot, és ennek az örökségnek zárolták egy részét - ehhez a család Kelley kegyvesztettsége miatt nem juthatott hozzá. A még hajadon Westonia így kezdi költői tevékenységét - ebben mindkét életrajzi hagyomány megegyezik, és irodalmi műveltségét eleinte szinte teljes egészében vagyonuk visszaszerzésének szolgálatába állítja. Westonia élete végéig ír, de Johannes Leóval való házassága, 1603 után költői aktivitása jócskán megcsappan. Fiatalon, 1612 november 23-án hal meg, hét gyermeke közül csak három lánya éli túl, négy fia nála korábban hal meg, s három lánya közül az egyik kerül házasság révén Eperjesre. ${ }^{36}$

Westonia életében nyomtatásban megjelent szövegeinek, illetve kiadásainak történetét újabban Schibel dolgozta fel. ${ }^{37}$ Kérdésfeltevése az, hogy ha Westonia tizenkilencéves korában két versét külön publikálja (16012), hogyan jelenhetett meg már egy évre rá az első összkiadás, és mik voltak a bizonytalan datálású, 1607-es vagy 1608-as második összkiadás keletkezési körülményei. Mivel gyakran említi Múzsája gyengeségét, Schibel feltételezése szerint mind a versek írásában, mind a korai publikálásban segítségre volt szüksége, nem beszélve arról, hogy befolyásos tudós támogatására lehetett szüksége ahhoz, hogy a versek a korabeli legnagyobb humanistáknál egyöntetü tetszésre találjanak. Az első nyomtatvány Cornelius Sutor nyomdájából került ki, kiadási dátuma 1601. július 19. Hosszú címe kiemeli, hogy a szerző nemes, poliglott, müvelt és - ami a legérdekesebb - két évvel megfiatalítja a költőnőt: tizenhat évesnek említi. Ez a marketing-fogás alighanem a csodagyermek-jelleget volt hivatva hangsúlyozni. A nyitóvers egy II. Rudolfnak szóló elégia, amely a későbbi két összkiadásban ugyanezen

\footnotetext{
${ }^{35}$ Hosington, i. m., 218.

36 SZÖRÉNYI, i.m., 14.

37 SCHIBEL, i. m., 278-284.
} 
a helyen marad. A második költemény hálaadó vers Johann Hellernek: ő akkoriban az Erfurti Egyetem jogi fakultásának dékánja - Westonia hálát mond neki, támogatást kér, és reflektál Heller kérésére, hogy mutassa be költői formában tudományos pályafutását. A ciklus többi verséből kiderül, hogy Heller számos lehetséges támogató, köztük prágai udvari jogászok pártfogásába ajánlotta Westoniát. A kiadvány Westonia Hellernak szóló levelét is közli, amelyben szerényen elhárítja Heller munkássága bemutatására vonatkozó kérését. A második nyomtatvány pár hónappal később, ugyanezen év végén jelenik meg. Nyitóverse a Megváltó születésére írt hosszú elégia. A címben Weston „csak” angol hajadon, a nemesség és egyéb korábbi attribútumok említése elmarad. A kísérőköltemény címzettje Rudolf főkancellárja, akitől már az apja, illetve az újabb életrajzi konszenzus szerint mostohaapja halála, 1597 vége óta meg nem kapott vagyonrészt említi, és segítséget kér ennek megszerzéséhez. A publikáció körülményeire utal, hogy egyik verse későbbi férjét, Johannes Leo udvari jogász segítségét kéri a már említett karácsonyi költemény publikálásában, majd egy másik verse már megköszöni a segítséget.

A két gyüjteményes kiadás szerkesztője Georg Martinius von Baldhoven, aki eredetileg talán nem csak szerkesztőként és verseinek javítójaként érdeklődött Westonia iránt, ezért talán csalódott is volt, amikor Westonia elfogadta Johannes Leo házassági ajánlatát. Az 1602-es első, Poëmata címmel megjelent összkiadás megjelenése után ő biztatja Westoniát, hogy kezdjen dolgozni egy bővített, leveleket is tartalmazó összkiadáson, mely Parthenicôn... Libri III címmel jelent meg 1607-ben vagy 1608-ban.

Westonia Frankfurtban megjelent első kötete, a von Baldhofen által szerkesztett Poëmata három nagy tematikai egységre oszlik. Az elsőbe javarészt alkalmi költemények: a költőnő háláját kifejező és címzettjeiket magasztaló versek tartoznak. A második csoportban disztichonok, és kizárólag állatokat szerepeltető tanmesék, példázatok. A költemények harmadik csoportját bölcselkedő és vallásos költemények alkotják. ${ }^{38}$

Westonia 1610-es költeményében nemtetszésének ad hangot dátum nélkül megjelent második, bővített összkiadása, ${ }^{39}$ a Parthenicôn

\footnotetext{
38 A kötet átfogó elemzése LATKÓCZY, i. m., 25-32.

39 SCHIBEL, i. m., 290 szerint a kötetben található tudós hajadonok és asszonyok katalógusa alapján Helena Maria Wackeriana a Wackenfels halála, 1607. május 30. a kiadás terminus post
} 
szerkesztéséről: valaki hevenyészett sorrendben adta nyomdába verseit, köztük első házaséveiből származó verseket is megjelentetett, ráadásul saját költeményeit kiadta az övéi között. A bünöst meg is nevezi: Georgius Carolides a Carlsperga, poeta Caesareus, császári költő az illető, Westonia egyik barátja. Hogy fér mindez össze a köztudott ténnyel, hogy a második összkiadást az elsőhöz hasonlóan von Baldhoven szerkesztette? Baldhoven az 1602-es Poëmata sikerén felbuzdulva mindjárt egy új, bővített leideni kiadást szorgalmazott, amihez a kor vezető humanistái, Scaliger, az idősebb Janus Dousa és Daniel Heinsius el is küldték az első kiadást méltató verseiket. Westonia el is kezd dolgozni az új kiadáson, de levélben közli Baldhovennel, hogy férje Prágában vagy Lipcsében szeretné megjelentetni a kötetet. 1603 decemberében aztán újabb levélben mond igent von Baldhovennek a leideni kiadásra, és megígéri, hamarosan küldi a kéziratot. Újabb másfél évbe telik, míg tudatja von Baldhovennel, hogy a kézirat kész, és felkéri, hogy gondozza a kiadást. Von Baldhoven válasza, ha volt is, nem maradt fenn. Akár igent mondott azonban a kérésre, akár nem, a neve a kötetre került, ami Schibel szerint marketing-fogás lehetett: a végül Prágában megjelent második összkiadást az első, sikeres Poëmata jó auspiciumai alatt akarták megjelentetni. Az imént idézett Westonia-költemény arra utal, hogy a prágai kiadást kinyomtatásáról Carolides gondoskodott, a kiadás Carolidestől származó záróversének címe pedig Westoniát saját versei kiadójaként nevezi meg. ${ }^{40}$ Schibel szerint von Baldhoven legalábbis a kiadás véglegesítésének munkálataiban már nem vett részt: alighanem jogi könyvének munkálataival volt elfoglalva. A második összkiadás néhány kivétellel (ilyen például a Weston mesteréhez, John Hammondhoz szóló költemény) magában foglalja a korábbi gyưjteményes kiadás anyagán kívül a Westoniához írt, munkásságát dicsérő, jelentőségét méltató költeményeket is, valamint a levelezést. A kötet szerkesztése tematikus: két verses könyve közül az első profán és elégikus

quemje, míg a Hosington-Cheney-kiadás a von Lobkowitz főkancellár tulajdonában lévő Parthenicon-példányra kézzel írt 1608-as dátumot valószínűsítik a kiadás évének. Ez az adat egyben megdönti azt a korábbi feltételezést, hogy a Dorothea Havlík halálára (1604. november 20.) írt elégia lenne a kiadás terminus post quemje, a könyv pedig 1605-ben, legkésőbb 1606-ban jelent meg. Az 1608-as dátumot valószínűsíti még SCHIBEL i. m., 290. Carolides ebben az évben jelentetett meg egy verses méltatást a Partheniconról a könyv kiadójánál, noha annál a kiadónál korábban nem publikált.

40 SCHIBEL, i. m., 288-94. 
hangvételü, a második vallásos költeményeket tartalmaz, a harmadik könyv pedig a leveleknek ad helyet.

Westonia költői hagyatékának és levelezésének első teljes magyar fordítását részben a Babits Mihály Müfordítói Ösztöndíj támogatásával készítettem, a kiadás körüli további munkákat az Antikvitás és Reneszánsz: Források és recepció MTA Támogatott Kutatócsoport tagjaként végzem. Eddig csak néhány mutatványt tettem közzé különböző irodalmi lapokban. ${ }^{41}$ Ezek egyike volt A Dunánál Kossuth-száma, melyben Westonia költeményeit Szörényi László a Kossuth- és a Weston-család kapcsolatáról szóló tanulmánya kísérte. ${ }^{42}$ Szörényi cikke összegzi a Westonia életrajzával kapcsolatos addigi álláspontokat, és a Kossuth-családdal való kapcsolatána lehetőségét is értékeli. Mint írja, Tardy Lajos vetett fel, hogy Kossuth Lajos anyja, Weber Karolina egyik felmenője a híres költőnő lenne. ${ }^{43}$ Tardy Westonéletrajza lényegében Latkóczy eredményein alapul. Westonia halála után Johannes Leo Bécsbe költözött, ahol hivatalos ügyek intézése közben került kapcsolatba a fentebb már említett Weber János eperjesi főbíróval, amikor az a felső-magyarországi öt szabad királyi város küldöttjeként Bécsben tárgyalt. Weber ekkor fiatal özvegy, és újra nősülni akar - egy udvari színházi előadáson ismerkedett meg Leóval és egyik lányával, a szintén fiatalon megözvegyült Johanna Elisabethával, akit 1643. július 28-án feleségül vett, és magával vitte Eperjesre. A házasságukból született négy fivér (Dániel, János, János György és János Frigyes) közül a két, Caraffa által 1687. május 9-én lefejeztetett testvér, Dániel vagy János Frigyes egyikétől származik a családi legenda szerint Kossuth anyai ágon, de mint a családfát kutató Gudenus

${ }^{41}$ Elisabeth WeSTON, De inundatione Pragae ex continuis pluviis exorta - Áradás Prágában a folytonos esőzések miatt, A Dunánál, 1(2002), 10. sz., NAGYILLÉS János (ford.); Elisabeth Weston kilenc verse, A Dunánál, 2(2003), 3. sz., 16-22, (A nemes és müvelt angol ifjúnak, Joannes Franciscus Westoniusnak, testvéröccsének; Sírverse fivére halálára, melyet a nôvéri szeretet $s$ a végtisztesség kifejezése végett írt 1600. november 4-én; A híres Mettheus Denichius Úrnak, az új Prága legnagyobb tudású orvosának, kedves barátomnak; Ioannes Leónak, hogy támogassa a Születési dalok kiadását; Szintén neki; Ovidius Keserveinek második könyvére; A sas és a teknösbéka; Barvitius kertjeire). Elisabetha Ioanna WESTONIA, Talpnyaló; Hírnév; A pletyka árt a hírnévnek; Nemessé csak az erény tesz; Kései intelem I, Bölcsesség I; Bölcsesség II; Sértett barátság I; Sértett barátság II., Kalligram - Müvészet és gondolat, 11(2004), 12.

42 SZÖRÉNYI, i. m., 12-15.

43 TARDY Lajos: Kossuth Lajos vértanú-őseiről (1687) = Régi feljegyzések Magyarországról, Bp., 1982,77 sk. 
János József megállapítja, a jelenleg rendelkezésre álló dokumentumok szerint nem állapítható meg biztosan, hogy melyiktől. ${ }^{44}$

A Susan Bassnett által valószínúsített életrajz a fentebbiektől sokban eltér. ${ }^{45}$ Bassnett kételkedik benne, hogy Westoniának valóban családi kapcsolata lett volna az említett Westonokkal, szerinte anyját Jane Coopert egy egyébként ismeretlen angol hivatalnok vette el tizenhat éves korában. ${ }^{46}$ Két gyermeket szült neki: Westoniát és fiútestvérét. Második férje John Dee segédje, Edward Kelley volt. Kelley Dee oldalán menekült családostul Angliából a kontinensre, ahol végül Prágában kötöttek ki az okkultizmus iránt élénken érdeklődő Rudolf udvarában. A nyelvek iránt nyilván egyébként is fogékony kislány legendás nyelvtudása Bassnett szerint Kelleynek köszönhető, aki - Dee-vel együtt - nemcsak Rudolfot szolgálta, hanem kémkedett is Prágában, s alkalmasint jó hasznát vehette a poliglott gyermeknek, mert a jelenlétében senki sem zavartatta magát, hogy mégoly kényes témákról is beszéljen. ${ }^{47}$ Kelley-t sem Westonia, sem humanista levelezőpartnerei nem említik korábban a költőnő anyjának, Jane-nek a halálánál.

Szörényi László idézett tanulmánya végén szellemesen női Ovidiusnak nevezi Westoniát. Noha nyelvezetének alapját a legkülönbözőbb klasszikus költők jelentik, ${ }^{48}$ a költőnő valóban igen gyakran hivatkozik Ovidiusra. Életének száműzetésként való felfogása, valamint a támogatásért könyörgő

\footnotetext{
44 Vö. GUDENUS i. m., 23-27.

${ }^{45}$ Non vidi. Feldolgozása: WeSTON, Collected Writings..., i. m., xi-xiii.

46 A plébániai anyakönyvi bejegyzések is fennmaradtak: John Wessone 1579. június 29-én vette el Joane Cowpert az oxfordshire-i Chipping Nortonban (WESTON, Collected Writings..., $i$. m., xii). A hölgy alighanem Thomas Cowper leánya, [?Jo]ane, akit 1563. június 28-án kereszteltek ugyanitt, annál is inkább, mert ez az adatolható keresztelési dátum összhangban van John Dee naplóbejegyzésével: Kelley felesége, Jane Cooper 1563. június 23-án született (WestON, Collected Writings..., i. m., xxix, 6. j.) E nász gyümölcse egy John nevü gyermek, akit 1580. július 23-án kereszteltek, és Elisabeth, akit valamikor 1581. március 4. és október 31. között kereszteltek meg. John Westont 1582. május 6-án temették. Egy héttel Weston halála előtt Mihály arkangyal kijelentette Edward Kelley-nek, hogy meg kell házasodnia, sőt az intést öt nap múlva meg is ismételte. Kelley röviddel Weston halála után feleségül is veszi a frissen megözvegyült Jane Cooper Westont, Westonia anyját.

47 SZÖRÉNYI, i. m., 14.

48 A Cheney-Hosington-kiadás bevezetőjében nem emel ki preferált alkotókat és müfajokat, felsorolása inkább a minták sokszínüségét látszik hangsúlyozni. Vö. WESTON, i. m., xv-xvi.
} 
verselégiák e költői pózról árulkodnak: Westonia egy hosszú elégiájában össze is veti saját sorsát Ovidiuséval. ${ }^{49}$ A költőnő valóban abban a müfajban alkotott a legtöbbet, amelyet Ovidius fő müfajának tekintünk: ez az elégia - a disztichonos formát a müfaj antik mintáihoz hasonlóan epigrammáiban, sőt a korabeli, von Baldhoven-féle gyưjtemény hét fabula Aesopicájában, aesopusi meséjében is használja. Ami az elégiát illeti, Westonia elégikus hangja sok tekintetben összevethető Ovidius számüzetési elégiáinak hangjával és tematikájával. ${ }^{50}$

Westoniát "nôi Ovidius"-szá azonban nemcsak versei formavilága és tematikája teszi, hanem az is, ahogy az ókori költészetre hivatkozik. Ennek alapos vizsgálata még közelebb juttat bennünket a költőnő mélyebb megértéséhez. ${ }^{51}$ Westonia költészetének latinul kellett szólnia, ami azt jelenti, hogy a klasszikusoknál nem adatolható latin kifejezések, kötések aránya nem léphette át azt a határt, amelyen túl e nyelv csak latin szavakkal, de nem latinul írt költői nyelv lett volna. Az alapos lexikai vizsgálat azt mutatja, hogy Westonia nyelvezete ugyanakkor meglehetősen egyéni és innovatív. Az utóbbi oka nemcsak nagyfokú önállósága, hanem az is, hogy mintáit kreatívan használja. Ezt részben tematikai, részben formai elvek határozzák meg. Elöképeinek kontextusvizsgálata arra enged következtetni, hogy alluzív tevékenységről nem annyira egyes locusok kapcsán, hanem inkább általánosabban, a költôi attitüd vonatkozásában beszélhetünk. Az általa használt költői elemek egyébként eredeti, addig „hallatlan” költői nyelvét

${ }^{49} \mathrm{Ch}-\mathrm{H}$ 70-73 In Ovidij. Trist. A vers magyar fordításban szintén megjelent: Elisabeth WESTON, Ovidius Keserveinek második könyvére, ford. NAGYILLÉS János, A Dunánál, 2(2003) 3. sz., 20-21.

50 Patricia DEMERS, Women's Writing in English: Early Modern England, Toronto, Buffalo, London, 2005, 140.

51 Westonia költői nyelvének mélyebb elemzését Schibel kezdeményezte az In Obitum NOBILIS ET GENEROSAE... címü, anyja halálára írt Weston-vers elemzésével SCHIBEL, $i$. m., 295-303. E költői nyelv feltérképezésére kísérletet tettem 2012-ben: NAGYILLÉS János, Verstechnik oder Allusion? Antike Vorbilder in der Dichtung von Elisabetha Johanna Westonia, 15th Congress of the International Association for Neo-Latin Studies (IANLS), Münster, 05-11 August 2012), s egyben vizsgálati módszerem eredményességét is teszteltem. Eredményeimet magyarul ismertettem a Hungaria Latina Magyarországi Neolatin Egyesület konferenciáján (Verselési technika vagy allúzió? Antik elóképek Elisabetha Joanna Westonia költészetében); Uö, Verstechnik oder Allusion? Antike Vorbilder in der Dichtung von Elisabetha Johanna Westonia, Acta Ant. Hung., 54(2014), 167-179. 
merőben formai alapon antik patinával látják el, bizonyos értelemben hitelesítik, tematikai kapcsolataik révén pedig segítenek a költőnőnek egyfelől a női Ovidius, másfelől pedig egy ovidiusi hősnő maszkját ölteni.

Ha egy költemény példáján ${ }^{52}$ szemügyre vesszük, ez miként történik, kiderül, hogy a nagy bizonyossággal származtatható minták száma oly nagy, hogy aligha lehet mindegyik költői utalás, a szelektáláshoz pedig olyan értelmezői önkény szükségeltetnék, amit bajosan engedhetnők meg magunknak. Egyfajta nyelvi kollázsról van tehát szó, melyben az elemek egyenkénti értelmezésének nemhogy nincs jelentősége, hanem az egyenesen félrevezető is lehet, amennyiben az értelmező célja az, hogy költőelődöktől vett elemekből egységes, önálló és saját jogán értelmezhető kép bontakozzék ki. Ezen az sem változtat, hogy a vers nyelvi anyagának biztos ovidiusi mintáiban a Tristia és Epistulae ex Ponto valamint a Hősnók levelei, a Heroides túlsúlya világosan kimutatható. Inkább arról lehet szó, hogy a fiatal (mai fogalmak szerint gyermek) Westonia e költeményeket mélyebb átéléssel és nyilván nagyon sokszor olvasta, egyrészt mert helyzetét egyfajta számüzetésként fogta fel, másrészt mert serdülő nőként saját hangját az ovidiusi Hôsnókében vélte megtalálni: ez lehet az oka, hogy a Heroides kifejezései gyakrabban tünnek fel verseiben.

Westonia teljes írásos hagyatékát 2000-ben Donald Cheney és Brenda Hosington publikálta kétnyelvű, latin-angol kiadásban. A szöveg alapjául Westonia két összkiadása szolgált, az 1602-es Poëmata és a bizonytalan keltezésü Parthenicôn. Mindkettőből több példányt vettek figyelembe, és az összevetés során kiderült, hogy rendszeres kollacionálásnak nincs értelme. Ugyan a korábbi Poëmata példányai két, tipográfiailag valamelyest különböző típusba sorolhatók, a két típusban található szövegek között lényegi különbség nincs. A jelek szerint szélesebb körben az 1606-os kiadású Parthenicát olvasták, több példány is maradt fenn belőle. Annak, hogy ez lett a Cheney-Hosington-kiadás alapja is, az az oka, hogy a Poëmata szövegét, ahol javítások vannak, még a szerző javította. A Parthenica három könyve a Westonia által és neki írt verseken kívül szintén általa és neki írt leveleket is tartalmaz, valamint hozzá tartozik egy Tudós hajadonok és asszonyok katalógusa is, amely hasonló katalógusokhoz képest újdonságot nem tartalmaz azon

\footnotetext{
${ }^{52}$ A költemény a válogatásban szereplő Ad eundem, de die S. Elisabethae Ch-H 14-17(SZINTÉN HOZZÁ Szent ERZSÉBET NAPJÁNAK megünnepléséről) címü darab.
} 
kívül, hogy a lista végén feltünteti önmagát is. A kiadás második része a Parthenicában nem található Weston-verseket, harmadik része pedig a Westoniának mások által írt verseket tartalmazza. A Cheney-Hosingtonkiadás által összegyűjtött 162 Westonia-költemény túlnyomó többsége, 158 darab formája distichon, a fennmaradó négy közül kettő a keresztény himnuszköltészet által is oly kedvelt jambikus dimeterben íródott - ezek a himnikus hangvételt és topikát is megőrzik. Egy további költemény formája Horatius 14. és 15. epódosáét idézi: ebben a hexametert dimetrum iambicum váltogatja. A vers Westonia I. Jakabnak írt levelét kíséri (1603). Egyetlen tisztán hexameterben írt darabja II. Mátyáshoz szól (1612), és nem sokkal Westonia halála előtt keletkezett. A distichonos költeményeket még Baldhoven kiadása alighanem müfaji alapon két nagyobb csoportra osztja: az 1. könyvbe kerültek a klasszikus elégia témáihoz közel álló disztichonos költemények, és a 2. könyv néhány hosszabb, vallásos témájú elégián kívül epigrammatikus tartalmú és terjedelmü, vallásos vagy világi témájú disztichonos darabokat tartalmaz, valamint a már említett fabulákat, melyeknek formája szintén disztichon. 